\title{
Symptoms of anxiety and depression among medical students: study of prevalence and associated factors
}

\section{Sintomas de ansiedade e depressão entre estudantes de medicina: estudo de prevalência e fatores associados}

\author{
Bartira Oliveira Sacramento' (D) bartiraos@gmail.com \\ Tassiana Lima dos Anjos' ${ }^{1}$ (D) tassianaanjos15.2@bahiana.edu.br \\ Ana Gabriela Lopes Barbosa' (1) anabarbosa15.2@bahiana.edu.br \\ Camila Fagundes Tavares' (D) camilatavares15.2@bahiana.edu.br \\ Juarez Pereira Dias' (1) juarezdias@bahiana.edu.br
}

\begin{abstract}
Introduction: Common Mental Disorders (CMDs) imply psychological distress, interfering with daily activities, interpersonal relationships and quality of life. It is estimated that CMDs affect $9 \%$ to $12 \%$ of the world's population and $12 \%$ to $15 \%$ of the Brazilian population in all age groups. Among different social groups, university students are more vulnerable to the development of anxiety and depression disorders.

Objective: Therefore, this study proposed to estimate the prevalence rates and factors associated with symptoms of anxiety and depression in medical students in a capital city of northeast Brazil.

Methods: This is a prevalence study, with a probabilistic sample of 1,339 students who regularly attended the 12 semesters of medical school in January 2018. Data were collected by applying a socioeconomic, behavioral and demographic survey and Beck Anxiety and Depression Inventories. The chisquare test was used to check for differences between anxiety and depression symptoms and socioeconomic and behavioral variables. The prevalence rates (total and by level of severity) and the crude and adjusted prevalence ratio (PR) were used as an association measure. Linear trend analysis was used to verify the existence of an association between anxiety and depression symptoms and semesters of the medical school. The variables that showed a crude PR with $\mathrm{p}<0.20$ were incorporated into the multivariate analysis, using the robust Poisson regression model, to determine the adjusted PR.

Results: The prevalence of symptoms of anxiety was $30.8 \%$, whereas depression was $36.0 \%$. The crude and adjusted PR for anxiety symptoms showed a statistically significant association with gender, age and sexual orientation. The crude and adjusted PR for symptoms of depression showed a statistically significant association with gender, ethnicity/skin color and sexual orientation. The correlation analyses between the semesters of the course and the presence of anxiety and depression symptoms indicated a weak coefficient of determination, with a descending characteristic and without statistical significance.
\end{abstract}

Conclusions: As this is a prevalence study, this investigation does not allow conclusions on causality. Additional follow-up studies are needed to elucidate the course of anxiety and depression throughout the school semesters.

Keywords: Anxiety; Depression; Medical Students; Medical Education.

\section{RESUMO}

Introdução: Os transtornos mentais comuns (TMC) implicam sofrimento psíquico e interferem nas atividades diárias, nos relacionamentos interpessoais e na qualidade de vida. Estima-se que os TMC atinjam de 9\% a 12\% da população mundial e de 12\% a 15\% da brasileira em todas as faixas etárias. Dentre os diferentes grupos sociais, os estudantes universitários possuem maior vulnerabilidade para desenvolver transtornos de ansiedade e depressão.

Objetivo: Diante disso, este estudo se propôs a estimar a prevalência e os fatores associados a sintomas de ansiedade e depressão em estudantes de Medicina de uma capital do Nordeste brasileiro.

Métodos: Trata-se de um estudo de prevalência, com uma amostra probabilística dos 1.339 alunos que frequentavam regularmente os 12 semestres do curso de Medicina em janeiro de 2018. Os dados foram coletados por meio da aplicação de questionário socioeconômico, comportamental e demográfico e dos Inventários de Ansiedade e de Depressão de Beck. Utilizou-se o teste de qui-quadrado para verificação de diferenças entre sintomas de ansiedade e depressão e variáveis socioeconômicas e comportamentais e as prevalências (total e por nível de gravidade) e a razão de prevalência (RP) bruta e ajustada como medida de associação. A análise de tendência linear foi empregada para verificar a existência de relação entre sintomas de ansiedade e depressão e semestres do curso. As variáveis que apresentaram RP bruta com $p<0,20$ foram incorporadas na análise multivaridada, no modelo de regressão de Poisson robusto, para determinação da RP ajustada.

Resultados: Quanto à prevalência de sintomas, constatou-se o seguinte: $30,8 \%$ para ansiedade e 36,0\% para depressão. A RP bruta e ajustada para sintomas de ansiedade teve associação estatisticamente significante para sexo, idade e orientação sexual. A RP bruta e ajustada para sintomas de depressão teve associação estatisticamente significante para sexo, raça/cor da pele e orientação sexual. As análises de correlação entre os semestres do curso e a presença de sintomas de ansiedade e depressão indicaram fraco coeficiente de determinação, caráter descendente e sem significância estatística.

Conclusões: Por se tratar de um estudo de prevalência, esta investigação não possibilita conclusões sobre causalidade. Estudos de acompanhamento adicionais são necessários para elucidar o curso da ansiedade e depressão ao longo dos semestres letivos.

Palavras-chave: Ansiedade; Depressão; Estudantes de Medicina; Ensino Médico.

1 Escola Bahiana de Medicina e Saúde Pública, Salvador, Bahia, Brazil.

Chief Editor: Daniela Chiesa

| Associate Editor: Roberto Zonato Esteves

Received on 09/04/20; Accepted on 12/06/20. | Evaluated by the double blind review process. 


\section{INTRODUCTION}

Common Mental Disorders (CMD) correspond to clinical conditions in which the individual has symptoms of anxiety, depression, sadness, fatigue, insomnia, stress, irritability, and somatic complaints, such as anorexia, dyspnea, and headache, among others ${ }^{1-3}$. However, these manifestations do not meet enough criteria for a formal psychological diagnosis of depression and / or anxiety according to the DSM-V (Diagnostic and Statistical Manual of Mental Disorders - $5^{\text {th }}$ edition) and ICD-11 (International Classification of Diseases - $11^{\text {th }}$ revision) classifications ${ }^{4,5}$, although they show an intensity and frequency capable of resulting in psychological distress for individuals, interfering in their daily activities, their interpersonal relationships and quality of life $\mathrm{e}^{1,2,6,7}$.

It is estimated that CMDs affect $9 \%$ to $12 \%$ of the world's population and $12 \%$ to $15 \%$ of the Brazilian population in all age groups ${ }^{8}$. According to the World Health Organization (WHO), this number has been increasing worldwide, especially in low-income countries, in females, the poorest and the unemployed, precisely those in which the symptoms of anxiety and depression are more frequent ${ }^{9-11}$. In Brazil, the prevalence of CMDs, according to several authors, ranges from $19.7 \%$ to $43.7 \%$, which represents a significant portion of the population that may require specialized care ${ }^{12,13}$.

Among the different social groups, university students are more vulnerable to the development of anxiety and depression disorders, and there have been studies that used different instruments, such as the Self-Reporting Questionnaire $(\text { SRQ-20) })^{14}$, the Beck Anxiety Inventory (BAI) ${ }^{15}$, and the Beck Depression Inventory $(\mathrm{BDI})^{16}$, which demonstrated its high prevalence, especially among medical students in several continents ${ }^{16,17}$. In economically developing countries, such as Egypt, a study carried out with 700 medical students in the year 2017 reported a high prevalence of anxiety, of $73 \%$, and a prevalence of depression of $65 \%{ }^{18}$. In Turkey, they found a prevalence rate of $35.8 \%$ for symptoms of medium and moderate anxiety and $30.5 \%$ for medium and moderate depression and $8.5 \%$ for severe depression ${ }^{19}$.

In turn, in Brazil in 2015, studies carried out with medical students from the state of Santa Catarina disclosed a prevalence of $35.5 \%$ and $32.8 \%$, respectively for anxiety and depression ${ }^{21}$. At Faculdade Pernambucana de Saúde (FPS), in 2014, the prevalence was $19.7 \%$ for anxiety and $5.6 \%$ for depression ${ }^{21}$.

Considering this scenario of high CMD frequency in university students, the aim of this study was to estimate the prevalence rate and factors associated with symptoms of anxiety and depression in medical students in a capital city in northeastern Brazil in 2018.

\section{METHODS}

This is a prevalence study, with a probabilistic sample of 1,339 students who regularly attended all 12 semesters of the medical course in January 2018 and who signed the Free and Informed Consent Form / Term of Assent. For the sample size calculation, we considered as parameters an expected mean prevalence of anxiety and depression symptoms in university students of $35 \%{ }^{20,22,23}$, an acceptable alpha error of $5 \%(a=5 \%)$, an effect of design of 1.5 and a $95 \%$ confidence level. The sample size was estimated at 417 students, which after adding $10 \%$ for losses and refusals, totaled 457 , divided proportionately, resulting in an average of 35 students per semester, which were selected by simple random drawing.

Data were collected by applying the following instruments: a) a structured questionnaire to record social, demographic, economic and behavioral information; b) Beck Anxiety Inventory (BAI) developed by Beck et al. (1988) ${ }^{15}$ and translated into Brazilian Portuguese and validated in Brazil in university students by Quintão et al. (2012) ${ }^{24}$ and c) Beck Depression Inventory (BDI) also developed by Beck et al. $(1961)^{16}$ and validated in the Brazilian Portuguese language, in Brazil, by Gorenstein and Andrade (1996) ${ }^{25}$ and GomesOliveira (2012) ${ }^{26}$. According to the cutoff points established by $\mathrm{BAl}$, a score $<10$ was considered as absence or symptoms of minimal anxiety; 11-19, mild; 20-30, moderate; and 30-63 points as severe anxiety, whereas in the BDI for symptoms of depression, a score $<10$ was considered as absent or minimal; 10-18, mild; 19-29, moderate; and 30-63 points, as severe depression. For this study, a score $>10$ was considered as the presence of anxiety and depression symptoms.

Descriptive analyses were carried out by distributing the absolute (n) and relative (\%) frequencies of the strata of the variables of interest. To check for possible differences between anxiety and depression symptoms and social, economic and behavioral variables, Pearson's chi-square test (x2) was used. The prevalence rates (total and by level of severity) and the crude and adjusted (Adj) prevalence ratio (PR) were used as a measure of association. The Kruskal-Wallis test was used to verify the difference between the prevalence rates, considering $\mathrm{p}<0.05$ as statistical significance.

The variables that showed a crude PR with $p<0.20$ were incorporated into the multivariate analysis using the robust Poisson regression model, to determine the Adj PR. The data were processed and analyzed using the SPSS software, version 22 and STATA version 15.1. The study project was approved by the EBMSP Research Ethics Committee, under N. 2,519,431 on February 28, 2018 and N. 2,572,959 on April 1, 2018. 


\section{RESULTS}

Of the 458 medical students (34.2\% of the total) included in the study, $62.7 \%$ were females and $60.0 \%$ were aged $<22$ years old. The median age for both genders was 22.0 years. A total of $92.6 \%$ of the students self-declared as heterosexual, $56.7 \%$ of white ethnicity/ skin color, $60.3 \%$ had a stable boyfriend/girlfriend and $48.1 \%$ were catholics. Regarding the monthly family income, $50.1 \%$ reported their income as being $<R \$ 8,000.00$. Students from the state where the medical school was located were $94.3 \%$, with the vast majority, $61.3 \%$, from the capital city. A total of $81.1 \%$ lived with family members (Table 1). Of the total number of students in the sample, $11.1 \%$ were in the first and tenth semesters of the medical course.

The prevalence of anxiety symptoms was $30.8 \%$, ranging from mild, in 91 (19.9\%), to moderate, in 39 (8.5\%) and severe in $11(2.4 \%)$ students. Minimal symptoms were identified in $289(63.1 \%)$ and absent in $28(6.1 \%)$ students. The prevalence of depression was 36.0\%, ranging from mild, in 132 (28.8\%), moderate, in 27 (5.9\%) and severe, in 6 (1.3\%) students. Symptoms were minimal in 259 (56.6\%) and absent in 34 (7.4\%) students (Chart 1).

Table 1. Prevalence of anxiety and depression symptoms in medical students according to demographic, social, economic and behavioral variables. Salvador BA. 2018.

\begin{tabular}{|c|c|c|c|c|c|c|c|c|c|c|}
\hline \multirow[t]{2}{*}{ Variable } & \multicolumn{5}{|c|}{ Anxiety } & \multicolumn{5}{|c|}{ Depression } \\
\hline & $\mathbf{n}$ & $\%$ & $\mathbf{n}$ & $\%$ & & $\mathbf{n}$ & $\%$ & $\mathbf{n}$ & $\%$ & \\
\hline \multicolumn{11}{|l|}{ Gender } \\
\hline Female & 107 & 37.3 & 180 & 62.7 & $0.000^{*}$ & 123 & 42.9 & 164 & 57.1 & $0.000^{*}$ \\
\hline Male & 34 & 19.9 & 137 & 80.1 & & 42 & 24.6 & 129 & 75.4 & \\
\hline$\leq 22$ & 97 & 35.4 & 178 & 64.6 & $0.011^{*}$ & 100 & 36.5 & 174 & 63.5 & 0.798 \\
\hline$>22$ & 44 & 24.0 & 139 & 76.0 & & 65 & 35.3 & 118 & 64.7 & \\
\hline \multicolumn{11}{|l|}{ Sexual orientation } \\
\hline Homo/bisexual & 20 & 60.6 & 13 & 39.4 & $0.000^{*}$ & 21 & 63.6 & 12 & 36.4 & $0.001^{*}$ \\
\hline White & 82 & 31.8 & 176 & 68.2 & & 82 & 31.8 & 176 & 68.2 & \\
\hline \multicolumn{11}{|l|}{ Affective status } \\
\hline With stable partner & 78 & 28.4 & 197 & 71.6 & 0.182 & 96 & 34.9 & 179 & 65.1 & 0.533 \\
\hline No stable partner & 62 & 34.3 & 119 & 65.7 & & 68 & 37.8 & 112 & 62.2 & \\
\hline \multicolumn{11}{|l|}{ Religion } \\
\hline Catholic & 62 & 28.3 & 157 & 71.7 & 0.274 & 70 & 32.0 & 149 & 68.0 & 0.081 \\
\hline Others & 78 & 33.1 & 158 & 66.9 & & 94 & 39.8 & 142 & 60.2 & \\
\hline \multicolumn{11}{|l|}{ Family income (R\$) } \\
\hline$\leq 12,000,00$ & 60 & 34.1 & 116 & 65.9 & 0.111 & 74 & 42.0 & 102 & 58.0 & $0.016^{*}$ \\
\hline Others & 25 & 29.1 & 61 & 70.9 & 0.680 & 41 & 47.7 & 45 & 52.3 & $0.012^{*}$ \\
\hline Family members & 116 & 31.4 & 254 & 68.6 & & 123 & 33.2 & 247 & 66.8 & \\
\hline
\end{tabular}

${ }^{*}$ statistically significant 
Chart 1. Prevalence of anxiety and depression symptoms in medical students. Salvador BA. 2018.

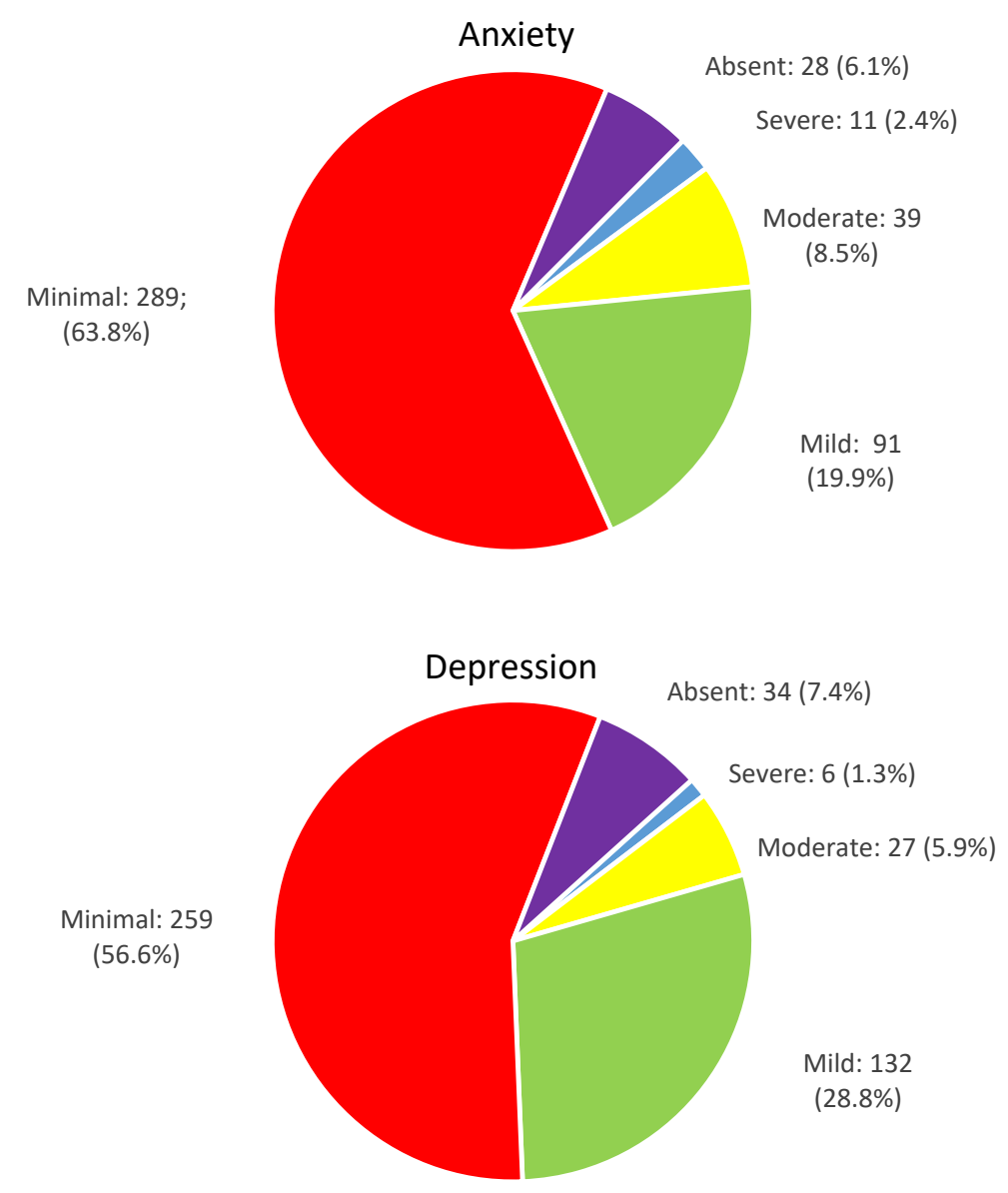

The crude PR of the association of anxiety symptoms and female gender, age $<22$ years and homo / bisexual sexual orientation, as well as the crude PR of the association of depression symptoms and female gender, homo / bisexual sexual orientation, other ethnicity / skin color (black/ brown), family income ( $<\mathrm{R} \$ 8,000.00)$ and living with others (colleagues/friend, hotel/boarding house / off-campus student residence) and alone showed a $\mathrm{p}$ value $<0.005$. In the robust Poisson model, the adjusted PR for anxiety symptoms retained a statistically significant association for gender (Adj. PR = 1.31; 95\%Cl [1.17-1.47]), age (Adj PR = 1.15; $95 \% \mathrm{Cl}[1.02-1.29]$ ) and sexual orientation (Adj. PR $=1.90$; 95\% Cl [1.26-2.86]) (Table 2). The adjusted PR for depression symptoms remained statistically significant for gender (Adj. $\mathrm{PR}=1.36 ; 95 \% \mathrm{Cl}$ [1.20-1.55]), ethnicity / skin color (Adj. PR = 1.96; 95\% Cl [ 1.29-3.04]) and sexual orientation (Adj PR = 1.19; $95 \% \mathrm{Cl}$ [1.03-1.36]) (Table 3). The prevalence rate of symptoms of anxiety and depression between the basic, intermediate and internship cycles did not show a statistically significant difference, respectively, $p=0.101$ and $p=0.601$.

Table 2. Prevalence rate, prevalence ratio and crude and adjusted confidence interval for anxiety symptoms in medical students according to demographic, social, economic and behavioral variables. Salvador, Bahia. 2018.

\begin{tabular}{ccccc}
\hline Variable & crude Odds Ratio & Confidence Interval & adjusted Odds Ratio & Confidence Interval \\
\hline Gender: Female & 2.39 & $1.53-3.74$ & 2.99 & $1.76-5.10$ \\
Age: $<22$ years & 1.72 & $1.13-2.62$ & 1.74 & $1.06-2.85$ \\
Sexual Orientation: homo/bisexual & 3.85 & $1.86-7.99$ & 3.94 & $1.74-8.91$ \\
Affective status & 0.76 & $0.51-1.14$ & - & - \\
Family income & 1.45 & $0.92-2.29$ & - & - \\
\hline
\end{tabular}


Table 3. Prevalence rate, prevalence ratio and crude and adjusted confidence interval for depression symptoms in medical students according to demographic, social, economic and behavioral variables. Salvador, Bahia. 2018.

\begin{tabular}{ccccc}
\hline Variable & crude Odds Ratio & Confidence Interval & adjusted Odds Ratio & Confidence Interval \\
\hline Gender: female & 2.30 & $1.51-3.50$ & 2.86 & $1.82-4.51$ \\
Sexual Orientation: homo/bisexual & 3.40 & $1.63-7.11$ & 5.08 & $2.30-11.22$ \\
Ethnicity/skin color: white & 1.53 & $1.04-2.25$ & 1.58 & $1.05-2.37$ \\
Religion & 0.71 & $0.48-1.04$ & - & - \\
Family income & 1.72 & $1.10-2.67$ & - & - \\
Lives with: family members & 1.83 & $1.14-2.94$ & 1.94 & $1.17-3.21$ \\
\hline
\end{tabular}

\section{DISCUSSION}

The prevalence of anxiety symptoms among medical students observed in the present study (30.8\%) was lower than those found by some other authors, which varied between $33.8 \%$ and $41.4 \%$, according to Ribeiro et al. (2020) ${ }^{27}$, Moutinho et al. (2017) ${ }^{28}$, Tabalipa et al. $(2015)^{20}$, Ediz et al $(2017)^{19}$ and Costa et al. (2020)23. However, these same authors indicated a prevalence of symptoms of depression between $8.2 \%$ and $34.6 \%$, therefore, lower than that of the present investigation (36.0\%). It has been established that symptoms of anxiety and depression are present in the daily lives of millions of individuals worldwide, affecting both their physical and mental health, especially university students and those in the health care field.

The disagreements regarding the prevalence rates found in the literature may have occurred due to regional and cultural differences among the student population, the used methodologies and types of questionnaires used to collect the data. However, it is a consensus that the medical course is seen as one of the most difficult courses that requires the students to concentrate their efforts on dedication to the studies and that there is high competitiveness among students ${ }^{29}$. The medical student's academic trajectory implies a long and arduous daily journey of activities, which implies in exhausting commuting that occupy even their time for social activities, leisure and even sleep hours ${ }^{30,31}$. Another extremely important factor is the contact with the patient's suffering, pain and even death, events that also cause tension and stress for medical students. This entire situation of physical and emotional exhaustion makes it difficult to take care of one's own health, whether due to the students' lack of time or negligence by the students and the school, increasing the risk of anxiety / depression symptoms and the development of burnout syndrome ${ }^{32,33}$.

The higher prevalence of anxiety and depression in

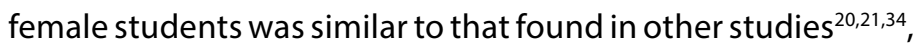
which is consistent with the Mental Health Information, according to which anxiety disorders were present in $23.4 \%$ of female individuals and in $14.3 \%$ of males ${ }^{35}$, as well as with the WHO statement, which states that worldwide, depression is more prevalent in women (5.1\%) than in men (3.6\%)' Such differences, according to the WHO, are a direct consequence of gender violence, socioeconomic disadvantage, income inequality, low or subordinate social status, social demands and responsibility for the care of other individuals, such as their offspring ${ }^{36}$. Other factors may also explain, in part, this higher prevalence, such as hormonal influences, considering that testosterone can have protective benefits against anxiety and depression ${ }^{37}$.

Individuals with homo/bisexual sexual orientation showed a higher prevalence of anxiety and depression symptoms when compared with heterosexuals also associated with these outcomes. Anguish, denial, doubt and even rejection, sometimes from the family itself are problems faced by this group of individuals, since the discovery and acceptance of their sexual orientation. Therefore, there is an increase in feelings of insecurity and psychosocial problems and a reduction in self-esteem, resulting in greater vulnerability to psychosocial problems such as drug use, depression and suicide attempts ${ }^{38,39}$. Similarly, a higher prevalence of depression symptoms was verified in students who declared themselves to be of nonwhite ethnicity/skin color (brown and black). This corroborates what was observed in a study with university students in the city of Rio de Janeiro ${ }^{40}$. Studies indicate that historical factors such as the lack of opportunities, both educational and socioeconomic, in addition to the stress associated with social roles and experiences such as racism and discrimination are considered important for the higher prevalence among black individuals than in white ones ${ }^{41,42}$.

The findings by Tabalipa et al. $(2015)^{20}$, Baldassin et al (2006) $)^{43}$ and Bastos et al. $(2016)^{40}$, of a higher frequency of anxiety symptoms in students from the first to the third years of medical school, precisely the younger ones, was similar to those of our study, explained by the better adaptation of the student to the course and the strengthening of interpersonal relationships with classmates, forming groups that share similar 
activities, such as study, leisure, travel, etc.

Although no association was found between symptoms of anxiety and depression and living with family members, support from one's parents is a source of strength for medical students to face difficulties during their studies and, at the same time, it also strengthens their self-confidence ${ }^{17,33,44}$.

Consistent with the literature, anxiety and depression symptoms were more frequent among students in the $3^{\text {rd }}, 5^{\text {th }}$ and $9^{\text {th }}$ semesters of medical school. Considering the course cycles, the basic one showed a higher prevalence than the other cycles, similar to that found by Costa et al. $(2020)^{23}$. Upon entering the university, students are faced with an environment that is completely different from what they had been experiencing in the previous years of study ${ }^{45,46}$. In the first years of college, during the period of the basic course, there is an urgent need for integration with the new colleagues and adaptation to the new teaching methodology, with an excessive amount of theoretical content, tests, seminars and other pedagogical demands, which end up stressing the students, resulting in the exacerbation of anxiety and depression symptoms ${ }^{44}$. This new teaching modality requires the student to develop cognitive and emotional capacity capable of meeting this new demand, which has a great impact on quality of life, with scarcity of free time and fatigue being mentioned by the students as the main factors that affect their quality of life ${ }^{47,48}$. In this study, the prevalence rates, both of anxiety and depression, also showed high values in the last cycle, the internship. It is believed that a closer contact with patients, often incorporating their worries, fears, anxieties and depression, makes the students into an extension of these patients, which, added to the expectation of finishing medical school, tests for medical residency programs and entering the labor market, collaborate to the increase in anxiety and depression symptoms ${ }^{48}$.

\section{CONCLUSION}

It is worth mentioning that some caution must be taken regarding the interpretation of some results of this study, as some questions involved aspects of "intimate nature", such as sexual orientation and family income. These aspects may have influenced the authenticity of the students' responses. Even though, as this is a prevalence study, this investigation does not allow conclusions about causality, its results represent an overview of the magnitude of the symptoms of anxiety and depression and their association with demographic, social, economic and behavioral factors. Additional follow-up studies are required to elucidate the course of anxiety and depression in this population group throughout the academic semesters, aiming to present a better understanding of the factors that influence these students' mental health and to aid in planning interventions to help them deal with the challenges they face.

\section{AUTHORS' CONTRIBUTION}

Bartira Oliveira Sacramento and Tassiana Lima dos Anjos: planning, collection, analysis and interpretation of data, writing and final review of the manuscript. Ana Gabriela Lopes Barbosa and Camila Fagundes Tavares: planning, collection and analysis of data. Juarez Pereira Dias: planning, analysis and interpretation of data, writing and final review of the manuscript.

\section{CONFLICTS OF INTEREST}

The authors declare no conflicts of interest related to this study.

\section{SOURCES OF FUNDING}

The authors declare there were no sources of funding for this research.

\section{REFERENCES}

1. Global Health Estimates. Depression and other common mental disorders. Geneva: World Health Organization; 2017.

2. Nunes MA, Pinheiro AP, Bessel M, Brunoni AR, Kemp AH, Benseñor IM et al. Common mental disorders and sociodemographic characteristics: baseline findings of the Brazilian Longitudinal Study of Adult Health (ELSA-Brasil). Rev Bras Psiq. 2016;(38):91-97.

3. Risal A. Common mental disorders. Kathmandu Univ Med J. 2011;35(3):213-7.

4. Figueiredo MSL. Transtornos ansiosos e transtornos depressivos aspectos diagnósticos. Rev SPAGESP. 2000;1(1):89-97.

5. Associação Psiquiátrica Americana. Manual diagnóstico e estatístico de transtornos mentais. 5a ed. rev. (DSM-V-TR). Porto Alegre: Artmed; 2014.

6. Soares GB, Caponi S. Depression in focus: a study of the media discourse in the process of medicalization of life. Interface Comun Saúde Educ. 2011;15(37):437-46

7. Organização Pan-Americana de Saúde. Folha informativa - Transtornos mentais. Washington, DC: Organização Pan-Americana de Saúde, Organização Mundial de Saúde; 2018.

8. Brasil. Diretrizes do NASF: Núcleo de Apoio à Saúde da Família. Brasília Ministério da Saúde; 2010.

9. Patel V, Burns JK, Dhingra M, Tarver L, Kohrt BA, Lund C. Income inequality and depression: a systematic review and meta-analysis of the association and a scoping review of mechanisms. World Psychiatry. 2018;17:76-89.

10. Prince M, Patel V, Saxena S, Maj M, Maselko J, Phillips MR, et al. No health without mental health. Lancet. 2007;370:859-77.

11. Chisholm D, Sweeny K, Sheehan P, Rasmussen B, Smit F, Cuijpers P, et al. Scaling-up treatment of depression and anxiety: a global return on investment analysis. Lancet Psychiatry. 2016;3:415-24.

12. Santos GBV, Alves MCGP, Goldbaum M, Cesar CLG, Giovanini RJ. Prevalência de transtornos mentais comuns e fatores associados em moradores da área urbana de São Paulo, Brasil. Cad Saude Publica. 2019;35(11):e00236318. doi: 10.1590/0102-311X00236318.

13. Moreira JKP, Bandeira M, Cardoso CS, Scalon JD. Prevalência de transtornos mentais comuns e fatores associados em uma população assistida por equipes do Programa Saúde da Família. J Bras Psiquiatr. 2011;60(3):221-6.

14. Harding TW, Arango MV, Baltazar J, Climent CE, Ibrahim HHA, LadridoIgnacio $L$, et al. Mental disorders in primary health care: a study of their frequency and diagnosis in four developing countries. Psychol Med. 1980;10:231-41.

15. Beck AT, Brown G, Epstein N, Steer RA. An inventory for measuring clinical anxiety: psychometric properties. J Consult Clin Psychol. 1988;56(6):893-7.

16. Puthran R, Zhang MWB, Tam WW, Ho RC. Prevalence of depression amongst medical students: a meta-analysis. Med Educ. 2016;50(4):456-68 
17. Pacheco JPG, Giacomin HT, Tam WW, Ribeiro TB, Arab C, Bezerra IM, et al. Mental health problems among medical students in Brazil: a systematic review and meta-analysis. Rev Bras Psiquiatr. 2017;39(4):369-78.

18. Fawzy M, Hamed SA. Prevalence of psychological stress, depression and anxiety among medical students in Egypt. Psychiatry Res. 2017;255:186-94.

19. Ediz B, Ozcakir A, Bilgel N. Depression and anxiety among medical students: examining scores of the Beck Depression and Anxiety Inventory and the depression anxiety and stress scale with student characteristics. Cogent Psychol. 2017;4(1):1-12.

20. Tabalipa FO, Souza MF, Pfützenreuter G, Lima VC, Traebert E, Traebert J. Prevalence of anxiety and depression among Medical students. Rev Bras Educ Med. 2015;39(3):388-94.

21. Vasconcelos TC, Dias BRT, Andrade LR, Melo GF, Barbosa L, Souza E. Prevalência de sintomas de ansiedade e depressão em estudantes de Medicina. Rev Bras Educ Med. 2015;39(1):135-42.

22. Leão AM, Gomes IP, Ferreira MJM, Cavalcanti LPG. Prevalência e fatores associados à depressão e ansiedade entre estudantes universitários da área da saúde de um grande centro urbano do Nordeste do Brasil. Rev Bras Educ Med. 2018;42(4):55-65.

23. Costa DS, Medeiros NSB, Cordeiro RA, Frutuoso ES, Lopes JM, Moreira SNT. Sintomas de depressão, ansiedade e estresse em estudantes de Medicina e estratégias institucionais de enfrentamento. Rev Bras Educ Med. 2020;44(1):e040.

24. Quintão $S$, Delgado AR, Prieto G. Validity study of the Beck Anxiety Inventory (Portuguese version) by the Rasch Rating Scale Model. Psicol. Reflex Crit 2013;26(2):305-10.

25. Andrade I, Gorenstein C, Vieira Filho AH, Tung TC, Artes R. Psychometric properties of the Portuguese version of the State-Trait Anxiety Inventory applied to college students: factor analysis and relation to the Beck Depression Inventory. Braz J Med Biol Res. 2001;34(3):367-74.

26. Gomes-Oliveira MH, Gorenstein C, Lotufo Neto F, Andrade LH, Wang YP. Validation of the Brazilian Portuguese version of the Beck Depression Inventory-II in a community sample. Rev Bras Psiquiatr. 2012;34:389-94.

27. Ribeiro CF, Lemos CMC, Alt NN, Marins RLT, Corbiceiro WCH, Nascimento MI. Prevalence of and factors associated with depression and anxiety in Brazilian Medical students. Rev Bras Educ Med. 2020;44(1):e021.

28. Moutinho ILD, Maddalena NCP, Roland RK, Lucchetti ALG, Tibiriçá SHC, Ezequiel OS, et al. Depression, stress and anxiety in medical students: a cross-sectional comparison between students from different semesters. Rev Assoc Med Bras. 2017;63(1):21-8.

29. Arnold SS, Carvalho EA. Predomínio do estresse em acadêmicos de medicina. Rev Uningá Review. 2015;24(1):85-9.

30. Trindade LMDF, Vieira MJ. Curso de Medicina: motivações e expectativas de estudantes iniciantes. Rev Bras Educ Med. 2009;33(4):542-54.

31. Fiorotti KP, Rossoni RR, Miranda AE. Perfil do estudante de Medicina da Universidade Federal do Espírito Santo, 2007. Rev Bras Educ Med. 2010;34(3):355-62
32. Benevides-Pereira AMT, Gonçalves MB. Transtornos emocionais e a formação em Medicina: um estudo longitudinal. Rev Bras Educ Med. 2009;33(1):10-23.

33. CMAJ. Medical schools addressing student anxiety, burnout and depression. CMAJ News. 2017;189:e1569-70

34. Sousa JM, Moreira CA, Telles-Correia D. Anxiety, depression and academic performance: a study amongst Portuguese Medical students versus nonMedical students. Acta Med Port. 2018;31(9):454-62.

35. National Institute of Mental Health. Mental Health Information [access in 20 apr 2020]. Available from: https://www.nimh.nih.gov/health/statistics/ index.shtml.

36. World Health Organization. Mental health [access in 20 apr 2020]. Available from: https://www.who.int/mental_health/prevention/genderwomen/en/.

37. McHenry J, Carrier N, Hull E, Kabbaj M. Sex differences in anxiety and depression: role of testosterone. Front Neuroendocrinol. 2014;35(1):42-57.

38. Everett BG. Optimal adolescent health to improve behavioral outcomes for LGBTQ youth. Salt Lake City: University of Utah; 2019.

39. Teixeira-Filho FS, Rondini CA. Ideações e tentativas de suicídio em adolescentes com práticas sexuais hetero e homoeróticas. Saúde Soc 2012;21(3):651-67 [access in 20 apr 2020]. Available from: http://www. scielo.br/scielo.php?pid=S0104-12902012000300011\&script=sci_arttext.

40. Bastos JL, Barros AJD, Celeste RK, Paradies Y, Faerstein E. Age, class and race discrimination: their interactions and associations with mental health among Brazilian universitystudents. Cad Saude Publica.2014 Jan;30(1):17586 [access in 20 apr 2020]. Available from: http://www.scielo.br/scielo. php?script=sci_arttext\&pid=S0102-311X2014000100175\&lng=en.

41. Almeida-Filho N, Lessa I, Magalhães L, Araújo MJ, Aquino E, James SA, et al. Social inequality and depressive disorders in Bahia, Brazil: interactions of gender, ethnicity, and social class. Soc Sci Med. 2004;59(7):1339-53.

42. Smolen JR, Araújo EM. Raça/cor da pele e transtornos mentais no Brasil: uma revisão sistemática. Ciênc Saúde Colet. 2017;22(12):4021-30 [access in 20 apr 2020]. Available from: http://www.scielo.br/scielo.php?script=sci arttext\&pid=S1413-81232017021204021\&lng=pt.

43. Baldassin SP, Martins LC, Andrade AG. Traços de ansiedade entre estudantes de medicina. Arq Méd ABC. 2006;31(1):27-31.

44. Mustafa MB, Nasirb R, Yusooffb F. parental support, personality, selfefficacy and depression among medical students. Procedia Social and Behavioral Sciences. 2010;7(C):419-424.

45. Vallilo NG, Danzi Júnior R, Gobbo R, Novo NF, Hübner CK. Prevalência de sintomas depressivos em estudantes de Medicina. Rev Bras Clin Med. 2011;9(1):36-41.

46. Audy J. A inovação, o desenvolvimento e o papel da universidade. Estudos Avançados. 2017;31(90):75-87.

47. Paro CA, Bittencourt ZZLC. Qualidade de vida de graduandos da área da saúde. Rev Bras Educ Med. 2013:37(3):365-75.

48. Moran JM. Os novos espaços de atuação do professor com as tecnologias. Revista Diálogo Educacional. 2004;4(12):13-21. 